\title{
FORGÓDUGATTYÚS ROBBANÓMOTOR FEJLESZTÉSE
}

\section{DEVELOPING AN INTERNAL COMBUSTION ENGINE HAVING ROTARY PISTON}

\author{
Dudás László ${ }^{1}$, Biró Máté ${ }^{2}$, Novák László Lajos ${ }^{3}$ \\ ${ }^{I}$ Miskolci Egyetem, Gépészmérnöki és Informatikai Kar, Alkalmazott Informatikai \\ Intézeti Tanszék, 3515 Magyarország, Miskolc-Egyetemváros; +36/46 565111/1414, \\ iitdl@uni-miskolc.hu

\begin{abstract}
${ }^{2}$ Miskolci Egyetem, Gépészmérnöki és Informatikai Kar, Alkalmazott Informatikai Intézeti Tanszék, 3515 Magyarország, Miskolc-Egyetemváros; +36/46 565111/1414, biroommate@gmail.com

${ }^{3}$ Miskolci Egyetem, Gépészmérnöki és Informatikai Kar, Alkalmazott Informatikai Intézeti Tanszék, 3515 Magyarország, Miskolc-Egyetemváros; +36/46 565111/1414, dariusz4424@gmail.com
\end{abstract}

\begin{abstract}
The paper presents the development process of a new internal combustion engine construction having rotary piston. The first part analyses the evolution of the antecedents, first shows the screw compressor line, than the progressive cavity type constructions are presented. As a consequent step of the motor evolution the paper introduces the construction of a new three dimensional rotary engine that has some advantages, in the second part. The main advantage of the new internal combustion engine is its simplicity. It has three rotary parts: the chamber, the rotor and the synchronising gear. The gas mixture moves in axial direction. The compression and the expansion of the explosive mixture happens in the caves formed between chamber and rotor. The initial theoretical modelling and visualisation was performed with Surface Constructor spatial kinematical modelling software application. The construction work to design the parts of the engine was carried out with a professional CAD software tool.
\end{abstract}

Keywords: internal combustion engine, rotor, rotary piston, design

\section{Összefoglalás}

A cikk egy új forgódugattyús belsőégésű robbanómotor kifejlesztését mutatja be. Az első rész elemzi az ősöket, elsőként a csavarkompresszor vonalat, majd a haladó üregű konstrukciók bemutatása következik. A motorevolúció ésszerü lépéseként a cikk a második részében bemutat egy új háromdimenziós forgódugattyús motorkonstrukciót, mely rendelkezik néhány elönyös vonással. Az új belsőégésü motor fő előnye az egyszerüsége. Három forgó alkatrészt tartalmaz: a kamra, a rotor és a szinkronizáló fogaskerék. A gázkeverék tengelyirányban mozog. A komprimálás és a tágulás a kamra és a rotor között kialakuló üregekben zajlik. A kezdeti elméleti modellezés és megjelenítés a Surface Constructor kinematikai modellező szoftverrel zajlott. A motor alkatrészeinek konstrukciós tervezése egy professzionális CAD szoftvereszközzel történt.

Kulcsszavak: belsöégésü motor, rotor, forgódugattyú, tervezés 


\section{Bevezetés}

Bár többen már temetik a robbanómotorokat, és az elektromos hajtás térnyerését látjuk, több olyan terület van még, ahol az energiaellátás hiánya és a súlyos és terjedelmes akkumulátorok miatt a robbanómotor még előnyben van. Ilyen pl. a mürepülés. Amíg használnak robbanómotorokat, azok fejlesztésének van létjogosultsága. Egyik nem is új irány a forgódugattyús motorok fejlesztése, mivel ezeknél elmarad az alternáló mozgást végző dugattyú az összes dinamikai hátrányával. A forgódugattyús motorok további előnyei a rezgésmentes járás, kevés alkatrész, nagy fordulatszám lehetősége stb. Az egyik legismertebb forgódugattyús motor kialakítás a Wankelmotor, melynek első konstrukciója csak forgómozgást alkalmazott, a későbbiekben tértek át a bolygódugattyús elrendezésre. A cikkben bemutatott motoroktól jelentősen eltér abban, hogy a konstrukciója lényegét tekintve síkbeli.

Jelen dolgozat az igazi térbeli, háromdimenziós forgódugattyús motorok kialakulását mutatja be, ehhez élő találmányi bejelentésekre, szabadalmakra utal. A forgódugattyús motorok elterjedése előnyeik ellenére még várat magára a tömítés problémái és a megszokott motoroktól eltérő gyártóberendezések, anyagok és egyéb csatlakozó szolgáltatások igénye miatt. Az alternáló mozgás ellenére még uralkodó hagyományos kialakítás a gyártásukra és karbantartásukra kiépült hatalmas iparág érdekei miatt nem szolgálja az új konstrukciók elterjedését. Remélhetőleg ez a cikk is tesz egy kis lépést a jóval egyenletesebb járású új szerkezetek elterjedése irányában. Mivel ezek a motorok még fejlődésük kezdetén tartanak, sok fejlesztési lehetőséget rejtenek a gyártómérnökök, az áramlástannal és hötannal foglalkozó kutatók, az anyagmérnökök és további területek szakemberei számára. Különösen az új anyagok, az ipari kerámiák alkalmazása hozhat áttörést ezeknél a súrlódás nélküli rotorral és forgókamrával müködő erőgépeknél.

A cikkben a szerzők egyikének találmányához vezető út bemutatása során ismertetésre kerülnek az egy- és többrotoros energiaátalakító berendezések. Az egyes kialakítások alkalmassága robbanómotor céljára, a már a geometriai kialakításukból is látható előnyeik és hátrányaik is elemzésre kerülnek a cikk elején. Majd részletesebben bemutatja a kifejlesztés alatt álló új motort, mely talán a világ legegyszerúbb kialakítású forgódugattyús robbanómotorja.

A cikk második részében az új motor gyakorlati kivitelezésére alkalmas alakjának tervezését mutatja be a dolgozat, néhány konstrukciós meggondolást és a kialakítás indoklását adva. A dolgozatot a konstrukciós munka eredményének, egy legyártható és a szerzők reménye szerint müködőképes motorkialakításnak a bemutatása zárja.

\section{A forgódugattyús motorok kifej- lődése}

A robbanómotorok elterjedtsége a termelés igen fontos szegmensét jelentő logisztikában, a jármüiparban a legnagyobb. Bár ezen a területen az elektromos meghajtás áttörésének korszakát éljük, egy kiemelkedő képességü robbanómotornak még lehetnek évtizedei az alkalmazásban, nem is beszélve a súlyra érzékeny repülésröl.

\subsection{Csavarkompresszor ősök}

Bár nem motor, de a tömítési kérdések hasonlósága miatt első konstrukcióként a gázsürítésre használt jól ismert kétrotoros csavarkompresszort kell említeni, melyet Henrich Krigar szabadalmaztatott Németországban 1878-ban a 4121-es számú találmánnyal [13]. Az ilyen kompresszorokban két összefonódóan kapcsolódó rotor működik, melyek az állórészben forognak. A rotorok állandó emelkedésű csavarfelületek, és a fogak profilja a csavartengely mentén 
nem változik. Kompresszor nevük ellenére a gépekben a gáz nem komprimálódik, azt csak szállítják, a sürüsödés a fogadó tartályban jön létre. Ha nagynyomású közeget vezetnénk a gépbe, akkor az motorként müködne, bár gyenge hatásfokkal, mivel táguló térrész csak a beömlő résznél van, utána a mozgó zárt térfogat állandó. Az 1. ábrán a [10] irodalom alapján mutatunk egy bevált konstrukciót.

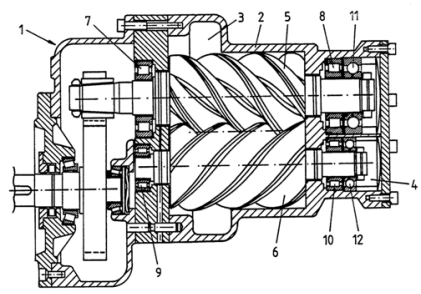

1. ábra. Csavarkompresszor

További variánsokat eredményez a rotor fogprofiljának, a menetek számának, a tengelyek közötti szögnek, valamint a csavarkerekek számának a változtatása $[2,11,12,20,28]$. Két forma a 2 . ábrán látható.
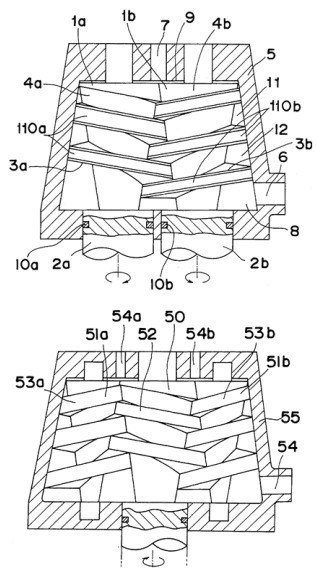

2. ábra. Két, vagy három kúpos rotorral rendelkezö közegtovábbitó gépek

Martin találmányában [14] egymáshoz folytonosan kapcsolódó eltérő osztású több csavarfelületü szakaszt tartalmazó csavar- kompresszor konstrukciót láthatunk, mely belső sürítésre képes (lásd 3. ábra).

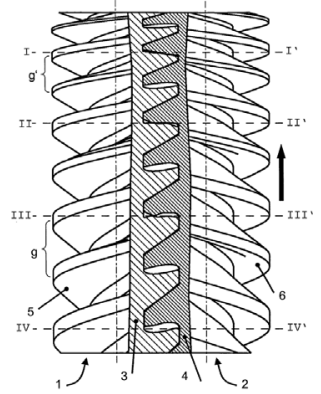

3. ábra. Eltérö osztásokkal rendelkezö rotorok, Martin és Sachse javaslata

Becher a 4. ábrán látható eltérő és folyamatosan változó osztással rendelkező rotorpárt mutatott be a [3]-ban.

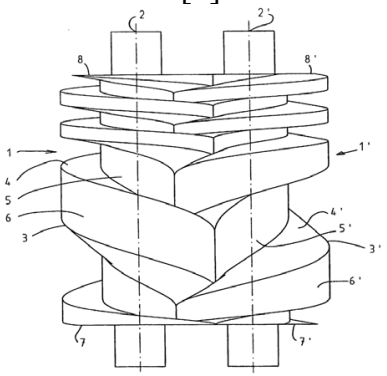

4. ábra. Folyamatosan változó emelkedésü csavarfelületü rotorok Becher javaslatában

North az elképzelést a fogmagasságra is kiterjesztette, amint az 5. ábrán látható [19].

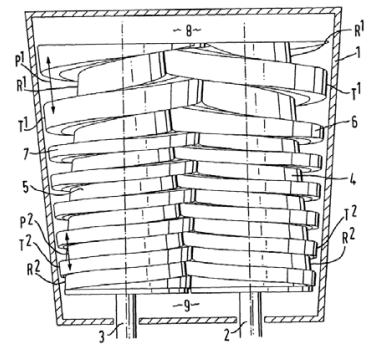

5. ábra. Rotorok változó osztással és fogmagassággal

Annak ellenére, hogy az említett csavargépek legtöbbje használható motorként 
külső nyomásforrással vagy külső robbanótérrel, ezek nem belsőégésü motorok.

Belsőégésű motorként alkalmazható kialakítást mutatott be Perna a találmányában [21], mely két, változó emelkedésủ és átmérőjü külső menettel rendelkező rotort tartalmaz, amint a 6. ábra mutatja.

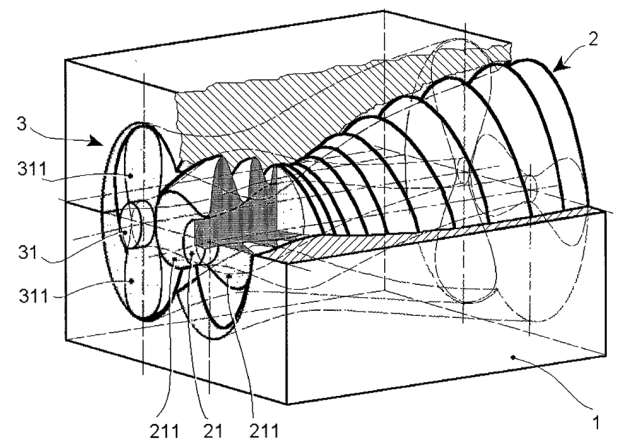

6. ábra. Perna belsőégésü motor találmánya

Mivel a szállítóüregek mérete ennél a konstrukciónál előbb szűkül, majd tágul, ez a gép használható belsőégésủ motorként. A feltaláló hangsúlyozta ezt és elhatárolta a találmányát a korábbi motortalálmányoktól, kiemelve a különbségeket és előnyöket. Mivel a legtöbb elhatárolás a cikkbeli motort megalapozó találmánnyal kapcsolatban is érvényes, Perna állításait ide emeltük: „Elvben mint sikerteleneket az ismert leírt csavarfelületű belsőégésű robbanómotorokat említhetjük. Az elrendezése az ilyen motoroknak eddig a kettő vagy több kapcsolt független berendezésekre, mint egy kompresszor és egy expanziós gép, korlátozódott. A hátránya ezeknek a megoldásoknak elsősorban a berendezés független részeiben megtestesülő munkatér alakjának és elrendezésének a beszíváshoz, sürítéshez, kitáguláshoz és kipufogáshoz, egy belsőégésủ motor különösen fontos folyamataihoz való korlátozott adaptációs képességét rejti magában. Az összes ismert berendezés nagyméretü. A tengellyel és henger alakú házzal rendelkezők elsősorban hosszú alakkal bírnak, a kúpos tengellyel és házzal rendelkezők pedig nagy átmérőjüek. Ezek a tulajdonságok még a rotor dinamikus kiegyensúlyozására is hátrányos hatásúak." Perna rotorkonstrukcióját két North-féle csavarrotorként képzelhetjük el.

A közös tulajdonsága az említett konstrukcióknak, hogy mindegyikük kettő, vagy több egymásba kapcsolódó csavarorsót alkalmaz melyek külső müködőfelülettel bírnak, és az álló ház belső felülete szintén érintkezik a mozgásban lévő folyadékkal vagy gázzal. Amint a csavargépek fejlődésének előbbi áttekintéséből látható volt, sok kis módosítás vagy hozzáadás vezetett végül a csavarkompresszor alapú belsőégésü robbanómotorhoz.

\subsection{A haladó üregú pumpa vonal fejlődése}

A fö geometriai felismerést, amely egy sokkal kompaktabb pumpakonstrukciót eredményezett, csavarfelületü rotorral és olyan házzal, mely eggyel több vagy kevesebb fogú belső konjugált felülettel bír, az 1930-as években dokumentálták [16,17,24]. Ezek a konstrukciók egy előnyös tulajdonsággal rendelkeznek: a konjugált felületek maguk zárnak közre üregeket, melyek axiális irányba mozognak, amikor a rotor és a forgó kamra egy megadott áttétellel forognak. Ezeknek a mozgó üregeknek köszönhetően ezek a gépek használhatók folyadék vagy gázközeg szállitására, és müködhetnek pumpaként, kompresszorként, folyadékvagy gáznyomás hatására üzemelő motorként, hasonlóan a két vagy több rotorral bíró csavargépekhez. Moineau gépében [17] a külső ház volt rögzített, és a rotor végezte a két egyesített excentrikus forgást, hasonlóan a Wankel-motor bolygódugattyújához. A 7. ábra mutat egy képet a szabadalomból [17].

A következő gép, amelyet említeni kell ebben a sorban, a FORCYL típusú vízpumpa [15], lásd a 8. ábrát.

Ennek a gépnek a két fö alkatrésze az 1 rotor és a 2 forgókamra. Az elv hasonló a 
Moineau-féle gépekéhez, de ez nem eggyel több, hanem eggyel kevesebb fogat alkalmaz a belső felülethez.

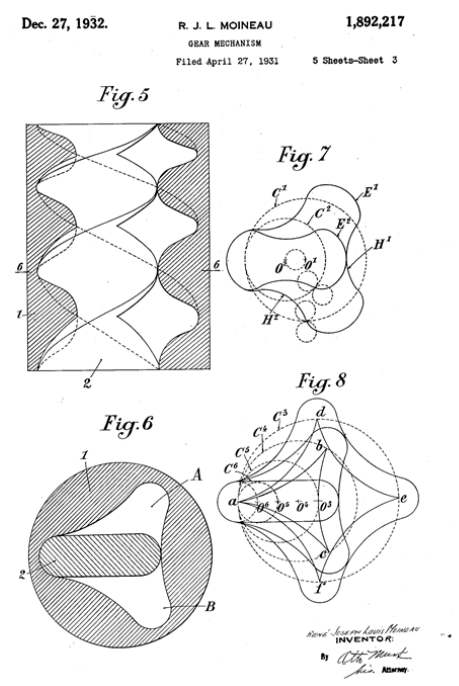

7. ábra. Moineau-féle ,fogaskerék-mechanizmus”

Azaz ebben a konstrukcióban a rotornak két foga van, a kamrának pedig egy. Még pontosabban a 11. ábrán 19-es számmal jelzett kamraprofil „félszög keresztmetszetü". Ezt a lehetséges kialakítást nem mutatták be a FORCYL típusú vízpumpa előtt. Ebben a konstrukcióban az aktív alkatrészek párhuzamos tengelyek körül forognak eltérő szögsebességgel ugyanabban az irányban.

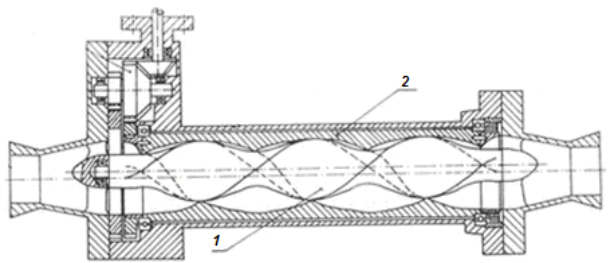

8. ábra. FORCYL típusú vízpumpa

A mozgás során a felületek zárt kamrákat alkotnak, melyek a tengelyek mentén egyenesen haladnak és szállítják a folyadék- vagy gázközeget. A jó tömítés érdekében az alkalmazott hézag közel nulla. Gázszivattyúk esetén vékony film kenés adja a légzáró tömítést az olajfolt tehetetlenségének köszönhetően, hasonlóan a csavarkompresszorokhoz [23]. A pontos felület lehet köszörült a szük rés biztosítására. Ez a köszörülő folyamat hasonló a csigák köszörüléséhez, és a köszörükorong profilja a jól ismert tervezőprogram csomagokkal, mint pl. a HELICAD [4] vagy a Surface Constructor $[5,6,7]$ meghatározható. A korongok számított felülete előállítható $\mathrm{CNC}$ korongszabályzókkal.

Új szabadalmak [24,26] módosított csavarfelületet alkalmaznak a tengely mentén a növekvő vagy csökkenő térfogatú üregek eléréséhez hogy kompresszorszerü vagy expanziós gépszerü müködést produkáljanak, lásd a 9. ábrát.

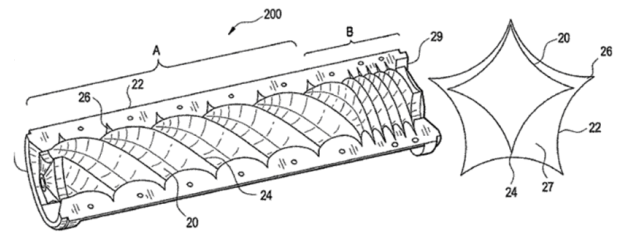

9. ábra. Nagy (A) és kicsi (B) osztás a MurrowGiffin szabadalomban [8]

Amint az ábra mutatja, a feltalálók két, eltérő emelkedésű csavarfelületet alkalmaztak. A táguló vagy sürítő hatás a két csavarfelület kapcsolódásánál jelentkezik. Ez a megoldás nem elönyös, mert a zárt üregek és következésképpen a nyomás csak egy igen rövid szakaszán jelentkezik a forgó alkatrészeknek. Továbbá az átmeneti részek geometriája és gyártásuk egyik szabadalomban sincs részletezve.

Jelen cikk egyik szerzőjének megoldása folyamatosan változó osztást alkalmaz a csavarfelületek teljes hosszában, lehetővé téve a nyomásváltozási hatás kiterjesztését hosszabb területre [9].

\section{Az új forgódugattyús motor}

A technika állásának áttekintése után a konklúzió az, hogy nem létezik a tágulókamra elvü szivattyúkon alapuló robbanómotor-konstrukció. Mivel ennek lehetnek 


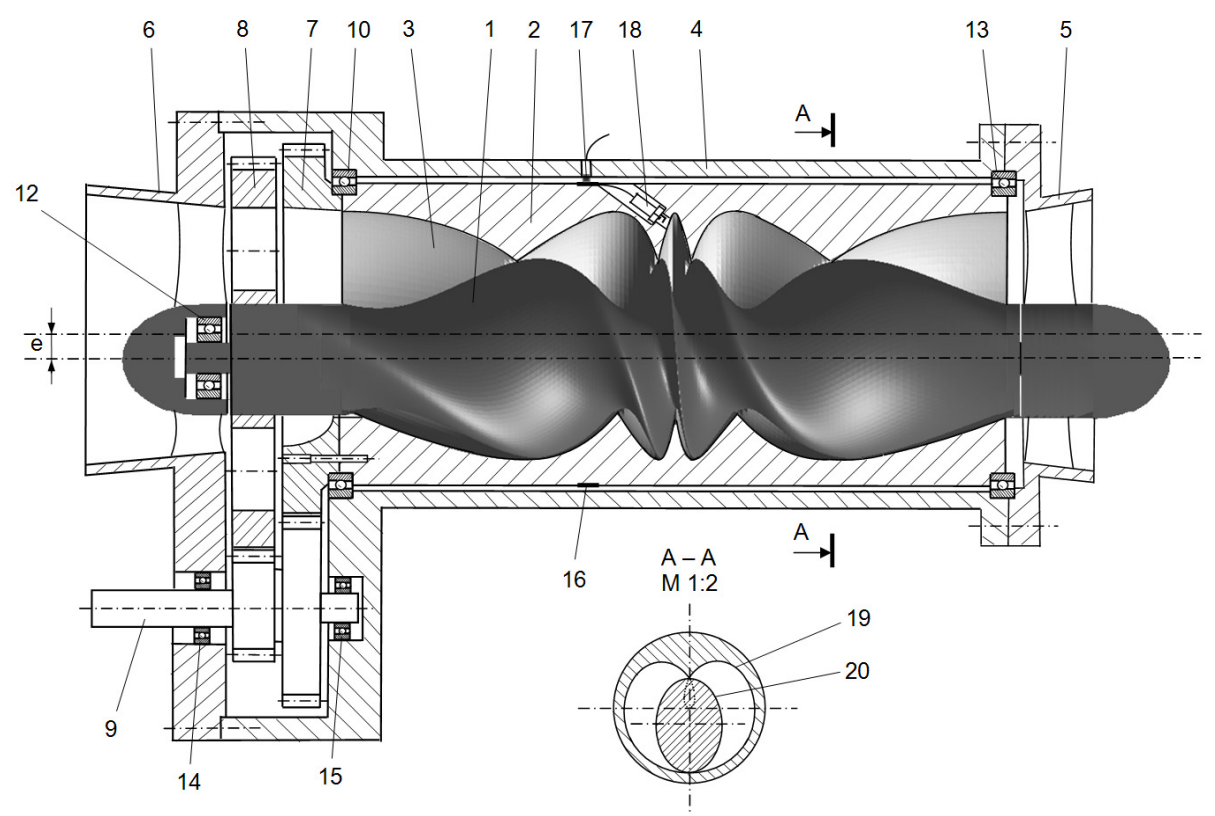

10. ábra. A találmány szerinti robbanómotor a rotorral (1), forgókamrával (2) és gyújtógyertyával (18)

előnyei, pl. kompaktság, egy kialakítás került bejelentésre. Egy fontos sajátossága a találmánynak [9] a kompressziós és expanziós igény kombinálása egy robbanómotorban, amint a 10. ábrán látható. Hasonló elv figyelhető meg Perna két- vagy többrotoros konstrukciójában.

A javaslat szintén integrálja a két funkciót egy új konstrukcióban, és a szerkezet közepén egy gyújtógyertyát alkalmaz. Hogy elhatároljuk ezt az új konstrukciót a korábban szabadalmaztatottaktól, a következő eltéréseket kell kiemelni:

-Ez a kialakítás eltér Perna konstrukciójától, mert egy forgókamrát alkalmaz egy belső működő felülettel, ezáltal egy kompaktabb kialakítást eredményezve. Az áthaladó gáz a két forgóelem által van közrezárva, az állórész felülete nem fontos ehhez a feladathoz.

-Ez a konstrukció eltér a Murrow-Giffin[18] vagy a Wiedenhofer-Rasheed- [26] gépektől, mert folytonosan változó osztást alkalmaz, és tartalmaz egy kompressziós és egy expanziós részt is. Továbbá része egy gyújtógyertya. A fö eltérés hogy a forgóháznak csak egy foga van.

A motor müködése nagyon egyszerü: a kompresszor rész beszívja a robbanókeveréket, süríti, majd a motor közepén lévő gyertya szikrája felrobbantja. Majd a kitáguló gáz forgatja a rotort és a forgókamrát, hogy tágítsa az üregeket azok között. Ez az egyik legegyszerübb robbanómotorkonstrukció a világon. A motor egy kétütemű működésű, szelep nélkül. Mivel nincsenek szelepek, nincs veszteség a szeleprugók összenyomásakor, azok mozgatásakor és a szelepvezérlő mü müködtetésekor. Nincs zaj és kopás a szelepek szelepülésen való felütközésekor, nincs ezek okozta vibráció, mely csökkentheti a motor megbízhatóságát és élettartamát. A fö dinamikai elönye a konstrukciónak a folyamatosan forgó, statikusan és dinamikusan kiegyensúlyozott részek alkalmazása, mindennemü alternáló 
mozgás nélkül, és ami még fontosabb, mindenféle rángatás és vibrálás nélkül. Nincs gyorsulása az alkatrészeknek a motor nagy fordulatszámánál. A robbanás periodikus hatását csökkenti a robbanótér alakja, a tengelyirányú erők a robbanás kezdetén kis gyorsító hatással bírnak, és a tangenciális erők, melyek a forgást okozzák, hosszabb tér- és időintervallumon át hatnak, simább müködést okozva. Nincs szükségtelen mozgás, a motor egyszerüen forog mindennemü csúszó tömítés nélkül, igen nagy fordulatszámokat lehetővé téve ezáltal. A sürítési és a tágulási arányok tetszőleges függvény szerint beállíthatók. Nincs lehetőség a keverék és a kipufogógáz keveredésére a motorban. A gáz lineárisan mozog a beszívótoroktól a kipufogónyílásig. A károsanyag-kibocsátás minimális értéken tartható, mert elnyújtott égés és ismételt gyújtás szintén lehetséges. Elégtelen égés és magas kibocsátási ráta elkerülhető a kipufogó szakasz kellő hosszúságúra tervezésével. Nincs szükség kipufogóra és hangtompítóra, mert a kipufogógáz nyomása olyan alacsony lehet, mint a légköri nyomás. Ipari kerámiát alkalmazva a rotor és a forgókamra anyagaként nincs szükség hütésre, ezáltal extrém magas hőmérséklet lehet a motorban. Az [1] forrásban bemutatott motorhoz hasonlóan olyan magas hőmérsékleten üzemelhet a motor, mely a fémmotorokat megolvasztaná. A magas hőmérséklet kevesebb el nem égett keveréket eredményez a kipufogógázban az égés hatásfokának növelése révén. Az alacsony hővezetésű kerámiáknak köszönhetően alacsonyan tartható a hőveszteség. A vízhütés hiánya egyszerübb felépítést eredményez, és magasabb energiahatékonyságot. Amint az [1,22] említi, a vízhütés $25-35 \%$-kal csökkenti a hatásos hőt a motorban. Egy további előny, hogy majdnem tetszőleges üzemanyag használható: bioüzemanyag, benzin, dízelolaj, JP8 repülőgép-üzemanyag, földgáz, növényi olaj és hulladékolaj.
További előnye a konstrukciónak a kiváló teljesítmény/súly arány, kevés alkatrész, nem változó hőállapot a motor mentén, azaz állandó fordulatszámnál állandósult hőmérsékletértékek adódnak, kiváló üzemanyagbeszívás és kipufogás, sima nyomaték- és teljesítményleadás. Rövidebb tömítési réshosszakkal üzemel, mint Perna gépe, és a forgókamra belső felületének az élén akár hagyományos csúszótömítés is alkalmazható.

Hátrányként említhető a 3D felületek előállítási költsége, a szük rés igénye miatti gyártási költség, a kis rés miatti nem tökéletes tömítés. A Redline [27] szerint a fizikai fordulatszám limit tényező extrém magas ennél a kialakításnál, könnyen túlszárnyalhatja a benzinmotorok 5000-7000 fordulat/perc értékét vagy a Mazda RX-8 Wankel-motorjának 9400-as fordulatszámát, sőt a versenymotorok 20000 fordulat/perc értékét. A motorban alkalmazott fogaskerék határfordulatszáma $40000 \mathrm{ford} / \mathrm{min}$ [25], nem korlátozó tényező. Nagyobb teljesítményigények esetén több forgókamra párhuzamosan építhető ugyanazzal a szinkronizáló fogaskerékkel.

\subsection{Motortervezés}

A motor fejlesztésének a következő lépése egy kinematikai, dinamikai modellezésre, áramlástani szimulációkra is alkalmas konkrét terv elkészítése, amely akár le is gyártható. A terv, figyelembe véve a későbbi gyártáshoz elérhető lehetőségeket, első lépésben nem kerámia anyagokkal számol, hanem hagyományos fémkonstrukcióval. Továbbá a motor mérete is kisebb, várható teljesítménye a méretéből eredően egy kézi fükasza motorjának értékét nem haladja meg.

Már a konkrét tervezés első lépéseinél jelentkezett Perna figyelmeztetése, miszerint a forgókamrás, axiális átömlésű motorokat a nagyobb hossz jellemzi. A geometriai kialakítás még a Surface Constructorral végzett elemzésnél megmutatta, hogy a zárt 
kamrák hossza jelentős, és a későn záruló, illetve hamar kinyíló kamrák miatt egyrészt hosszabb motorral, másrészt a középső részen sürübb menetemelkedéssel kell számolni. Ezen utóbbinak viszont ellene hat a gyárthatóság, melynél kétféle lehetőséget elemeztünk. Az első elképzelést, a forgókamra 3D-s szoborfelületként való megmunkálását félgömb végü forgácsolószerszámokkal első lépésben elvetettük, mivel egyrészt vékony árokban kellene nagy kinyúlású szerszámmal dolgozni, másrészt alámetszés is fellép a tengelye mentén osztott kamra belső alakos felületén a tengelymetszeti profil kvázi kardioid alakja miatt. A második elképzelés, az osztott kamrafelek kinagyolása külön-külön teknőszerüen, az alámetszésnek megfelelő ráhagyással, majd a két félből összeszerelt üreges kamra végső alakra hozása és simító megmunkálása a származtatáshoz alkalmazott ellipszisekbe illeszkedő tárcsaszerű szerszámmal reálisabbnak tünt. Itt is szükséges azonban erősített szárú szerszám a viszonylag hosszú kinyúlás miatt. Az alkatrészek megmunkálhatóságánál további szokatlan igény nem merült fel.

További megfontolást igényelt a gáz átáramlási irányának megválasztása. Ennél abból indultunk ki, hogy az önálló olajkenéssel ellátott szinkronizáló fogaskerék áttétel a kiáramlási oldalon legyen, ahol már az olajat lemosó benzines keverék nem éri.

A konstrukció kialakítása a technológiai megfontolások után a szokásos gépészmérnöki ismeretek felhasználásával történt. A szerkezetbe a rotor és a forgókamra közé tervezett igen kis hézag könnyebb biztosíthatósága érdekében egy, a rotor és a kamra relatív szöghelyzetének finomállítását lehetővé tévő excenteres beállító egységet is beterveztünk. A professzionális CAD rendszerben történt konstrukciós tervezés eredményét a 11. ábra mutatja.

Egy izgalmasabb résznek még a robbanókeverék berobbantásáért felelős szikraképző elektronika és ,gyújtógyertya” kiala-

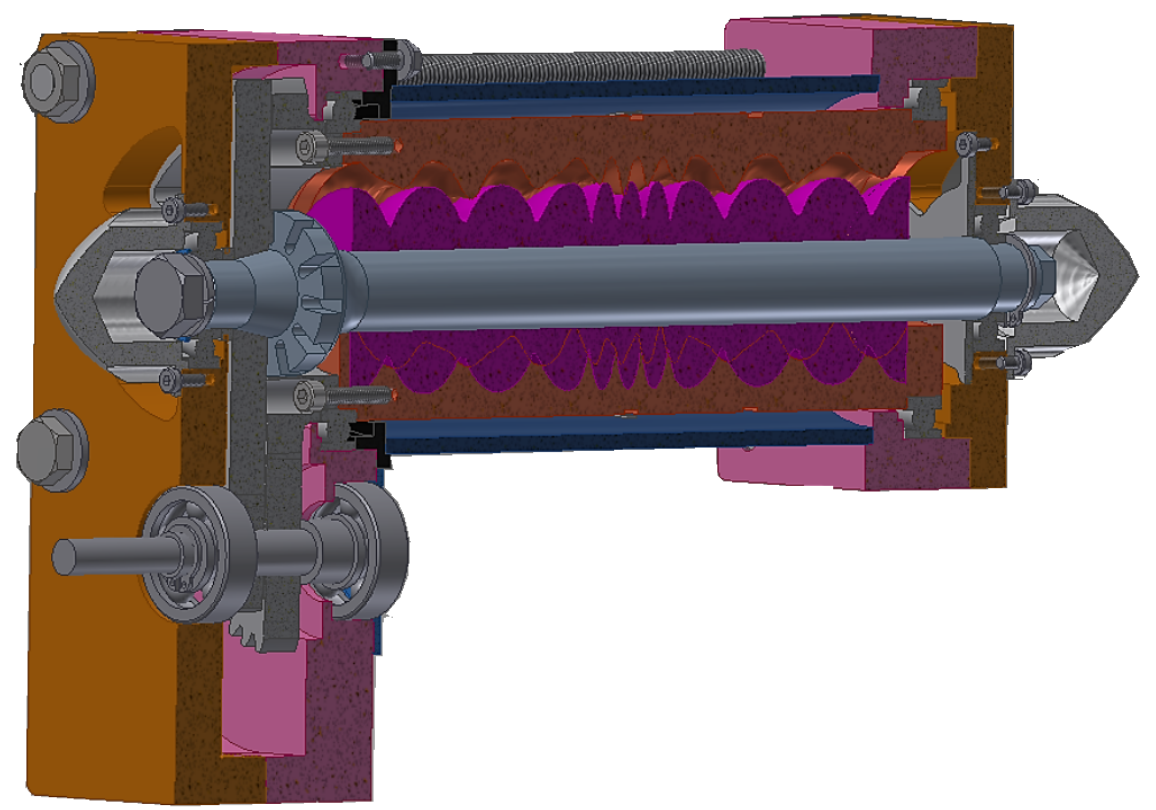

11. ábra. A kifejlesztett forgódugattyús motor metszeti nézete 
kítása tünik. A problémát a szikraképzéshez szükséges nagyfeszültség igénye okozza, amelynek a ,gyújtógyertyához" történő odavezetése a forgókamra miatt nem triviális. A tervezett módszer azzal számol, hogy a gépjárművekben szokásos módon a testet maga a fémszerkezet adja, és elegendő csak egy pólusnak a csúszógyürü-csúszókefe pároson történő átvezetése.

Reményeink szerint a közeljövőben lehetőségünk nyílik a terv realitásának tesztelésére és a szerzett tapasztalatok alapján a konstrukció finomítására.

\section{Következtetések}

A cikk áttekintette a forgódugattyús belsőégésü motorok fejlődését szabadalmi bejelentéseken keresztül. Bemutatta a szerzők egyikének találmányát, mely a világ egyik legegyszerübb motorja, számos elönyös tulajdonsággal. A második rész ismertette egy konkrét konstrukció kialakításához vezető gyárthatósági, szerkezeti és müködési megfontolásokat, és bemutatta a tervezés eredményét. A továbbiakban a prototípus megépítése és kísérletek végzése kell hogy bizonyítsa a várakozásokat, és tapasztalatokat adjon a szerkezet finomításához.

\section{Köszönetnyilvánítás}

Ez a projekt a TÁMOP-4.1.1.C12/1/KONV-2012-0002 „Jármüipari Felsőoktatási és Kutatási Együttmüködés" projekt keretében került kidolgozásra. A projektet támogatta a Magyar Kormány, valamint az Európai Szociális Alap.

\section{Szakirodalmi hivatkozások}

[1] 2012 Ceramic Rotary Engines, Inc: Ceramic Rotary Engine,

$\mathrm{http} / / \mathrm{www}$. youtube.com/watch? $\mathrm{v}=$ YnfFEf7wyww, Elérve: 2013. dec. 20,.

[2] Abe, Y., Maruyama, T.: Fluid rotary apparatus having tapered rotors. United States patent US 5533887 A, 1996 http://www.google.no/ patents/US5533887, Elérve: 2013. aug. 21.
[3] Becher, U.: Twin screw rotors and displacement machines containing the same. United States patent US 20030152475 A1, 2003, https://www. google. no /patents/US20030152475, Elérve: Aug. 21, 2013.

[4] Dudás, L.: Resolution of Geometrical Problems of Contacting Surfaces Using the Reaching Model. Thesis for Candidate of Technical Science Degree, Hungarian Academy of Sciences, Budapest,1993.

[5] Dudás, L.: Surface Constructor - a Tool for Investigation of Gear Surface Connection. Proceedings of CIM 2003 Advanced Design and Management Conference, Wydawnictwa Naukowo-Technicne, Warszava, 2003. pp. 140-147.

[6] Dudás, L.: Advanced Software Tool for Modelling and Simulation of New Gearings. International Journal of Design Engineering IJDE Vol. 3, No.3, 2010. pp. 289-310.

[7] Dudás, L.: Gear Investigations Based on Surface Constructor Kinematical Modelling and Simulation Software. Proceedings of UMTIK 2010 14th International Conference Machine Design \& Production, Güzelyurt, T.R. Northern Cyprus, 2010. pp. 731-742.

[8] Dudás, L.: Modelling and Simulation of a Novel Worm Gear Drive having Point-like Contact. Proceedings of TMCE 2010 Symposium, Edited by I. Horváth, F. Mandorli and Z. Rusák, Ancona, 2010. pp. 685-698.

[9] Dudás, L.: Forgódugattyús belsőégésü motor. Magyar szabadalom P1100552 Bejelentve 2011. szept. 3, Közzétéve 2013. május 28.

[10] Jacobsson, B. O., Gabelli, A.: Screw compressor. European patent EP0376373 A1, 1990, http://www.google.com/patents/ EP0376373A1?cl=en, Elérve: 2013. aug. 21.

[11] Jones, W. A.: Motor. United States patent US $678570 \quad \mathrm{~A}, \mathrm{http}: / /$ www.google. no/patents/ US678570, 1901, Elérve: 2013. aug. 21.

[12] Kapp, B.: (), Improvements in Screw Pumps. Patent GB696732 (A), http://worldwide.espacenet.com/publication Details/biblio?CC $=\mathrm{GB} \& \mathrm{NR}=696732 \mathrm{~A} \& \mathrm{KC}$ $=\mathrm{A} \& \mathrm{FT}=\mathrm{D} \& \mathrm{ND}=\&$ date $=19530909 \& \mathrm{DB}=$ 
\&locale=en_EP, 1953. Elérve: 2013. aug. 21.

[13] Mann, D.: Compressor System Technology: Evolutionary Potential and Evolutionary Limits. http://www.systematic-innovation. com/Articles/05/Feb05-Compressor System Technology-Evolutionary Potential and Evolutionary Limits.pdf, 2005. Elérve: 2013. aug. 21.

[14] Martin, H., Sachse, R.: Rotors for a screw compressor. Patent EP 1722104 A2, https://www. google.no/patents/EP1722104 A2?hl=hu\&cl=en, 2006, Elérve: 2013. dec. 21.

[15] Micro Europe Kft.: A Sokszögmegmunkálás élvonalában (In the Frontline of Polygon Surface Machining), http://www.microeur ope.hu/indexsziv.html, 2012. Elérve: 2012. febr. 19.

[16] Moinean, B. J. L.: Gear Mechanism. United States patent US RE21374 E, 1940. http://www.google.com.tr/patents/USRE21 374, Elérve: 2013. aug. 21.

[17] Moineau, L. R. J.: (), Gear Mechanism. United States patent US 1892217 A, http://www.google.com.tr/patents/ US1892217, 1932, Elérve: 2013. aug. 21.

[18] Murrow, K. D., Giffin, R. G.: Axial Flow Positive Displacement Turbine. United States patent 2009/0226336 A1

[19] North, M. H., (), Screw vacuum pump. United States patent US 20010024620 A1, http://www. google.com/patents/US200100 24620?hl=hu\&cl=en, 2001. Elérve: 2013. dec. 21.

[20] Oscar, L., Rich, J. P., Thompson, N.: Intermeshing screw pumps and the like. United States patent US 2908226 A, http://www.google.no /patents/US2908226, 1959. Elérve: 2013. aug. 21.
[21] Perna, V.: Equipment with mutually interacting spiral teeth. United States Pat. US 20030012675 A1, http://www.google.de /patents/US20030012675, 2003. Elérve: 2013. dec. 21.

[22] Ronney, P. D.: Hydrocarbon-fueled internal combustion engines: "the worst form of vehicle propulsion... except for all the other forms". http://ronney.usc.edu/whyicengines /WhyICEngines.pdf, Elérve: 2013. dec. 21.

[23] Stosic N., Smith I. K., Kovacevic, A.: Opportunities for Innovation with Screw Compressors. Proceedings of the Institution of Mechanical Engineers, Part E: Journal of Process Mechanical Engineering, Vol. 217 No. 3, 2003. pp.157-170. http://www. staff.city.ac.uk/ ra601/oportsvi.pdf, Elérve: 2013. aug. 23.

[24] Taylor, A., Ashbourne, E. P. S.: Helical gear pumps. United States patent US 3168049, http://www.google.com.tr/patents /US3168049, 1965. Elérve: 2013. aug. 21.

[25] Triveni Engineering \& Industries Ltd. product catalogue: High Speed Gears and Gearboxes. http://www.trivenigroup.com/ download/gearbox-catalogue.pdf, Elérve: 2013. dec. 21.

[26] Wiedenhoefer, J. F., Rasheed, A.: Noncontact seal for positive displacement capture device. United States patent US 20090220369 A1; 2009. http://www. patentgenius.com/patent/7837451.html, Elérve: 2013. aug. 21.

[27] Wikipedia: Redline. http://en.wikipedia. org/wiki/Redline, 2008, Elérve: 2013. dec. 21.

[28] Yoshihiro, M., Toshio, M.: Rotary gas motor and compressor with conical rotors. United States patent US 3116871 A, 1964. http://www.google.no/patents/US3116871, Elérve: 2013. aug. 21. 